\title{
Records of the dusky dolphin (Lagenorhynchus obscurus) in the Falkland Islands, including associations with Peale's dolphin (L. australis)
}

\author{
Caroline R. Weir ${ }^{1 *}$ and Andy Black²
}

\begin{abstract}
Background: The status of the dusky dolphin (Lagenorhynchus obscurus) around the Falkland Islands (south-west Atlantic) has been long debated, since most records published to date lack supporting information. There is also considerable scope for confusion with the sympatric Peale's dolphin (L. australis), which has a similar external appearance.

Results: A literature review confirmed one previously-published record as dusky dolphin; a skull that apparently originated from the Falklands in 1955. Four new photographically-supported records of dusky dolphin are described, comprising three sightings and one live stranding. Two sightings consisted of the same dusky dolphin individual in a mixed-species association with Peale's dolphins in coastal waters. An additional sighting established their use of deep, offshore waters around the Falklands.

Conclusion: The dusky dolphin is a confirmed component of the Falkland Islands cetacean community, but appears to be relatively uncommon. The first documented occurrences of an association between dusky and Peale's dolphins emphasises the need for vigilance when identifying dolphins during cetacean surveys in the wider South American region.
\end{abstract}

Keywords: Distribution, Species identification, Mixed-species association, Falklands, South-West Atlantic

\section{Background}

The taxonomy of the Lagenorhynchus genus is unresolved and under continued scientific review (Harlin-Cognato and Honeycutt, 2006). Six species of dolphin are currently-recognised in the genus, comprising three each in the Northern and Southern Hemispheres respectively. The spatial distributions of the three Southern Hemisphere Lagenorhynchus species, the dusky dolphin ( $L$. obscurus), Peale's dolphin (L. australis) and hourglass dolphin (L. cruciger), are relatively poorly-documented compared with their counterparts in the Northern Hemisphere (Cipriano and Webber 2010).

The dusky dolphin is distributed widely, but probably discontinuously, in the Southern Hemisphere and is

\footnotetext{
* Correspondence: swpo@conservation.org.fk

${ }^{1}$ Falklands Conservation, Jubilee Villas, Stanley FIQQ 1ZZ, Falkland Islands Full list of author information is available at the end of the article
}

currently considered to be a globally Data Deficient species (Hammond et al. 2008). It inhabits cold, shelf waters off southern Africa, South America, New Zealand, southern Australia, and around some oceanic island groups (Van Waerebeek et al. 1995; Cipriano and Webber 2010). In the south-west Atlantic Ocean, dusky dolphins have been recorded from approximately $36^{\circ} \mathrm{S}$ off Argentina southwards to $57^{\circ} 50^{\prime} \mathrm{S}$ near Cape Horn, and they are considered to be one of the most numerous delphinid species off the Argentinean coast (Crespo et al. 1997). Their occurrence in the southernmost portion of the south-west Atlantic remains poorly understood. They appear to be uncommon in nearshore waters at the southern tip of South America around Tierra del Fuego and the Beagle Channel, but do occur in large open bays and offshore waters in that area (Goodall et al. 1997; Crespo et al. 1997). 
There has long been uncertainty regarding the occurrence of dusky dolphins in the Falkland Islands, an archipelago located at latitudes of 51 to $53^{\circ} \mathrm{S}$ in the South Atlantic approximately $500 \mathrm{~km}$ to the east of South America. The present study evaluates published records of dusky dolphins around the Falklands and provides novel information in the form of several photographically-supported observations. We also report the first mixed-species associations between dusky dolphins and Peale's dolphins, and highlight the potential for confusion between these similar species during cetacean surveys in the wider region.

\section{Methods}

\section{Study area}

The study area included the Falkland Islands Interim Conservation and Management Zone (FICZ) and the Falkland Islands Outer Conservation Zone (FOCZ), which together extend from the coast to the 200 nautical mile economic zone boundary around the Falklands (Fig. 1). The islands are situated in shallow waters (< $200 \mathrm{~m}$ depth) over the Patagonian continental shelf which stretches eastwards from South America. Deeper water associated with the shelf edge occurs to the north, east and south of the Falklands, with the $1000 \mathrm{~m}$ isobath located approximately $100 \mathrm{~km}$ offshore at its nearest points. Offshore sea surface temperatures (SST) range between $6{ }^{\circ} \mathrm{C}$ in winter to $10-13{ }^{\circ} \mathrm{C}$ in summer, and the coastal SST ranges from $2{ }^{\circ} \mathrm{C}$ in winter to $14{ }^{\circ} \mathrm{C}$ in summer (Otley et al. 2008).

\section{Dusky dolphin records}

A literature review was carried out in December 2017 to locate published records of dusky dolphins in the Falklands. The ISI Web of Knowledge and Google Scholar were searched for the terms 'dusky dolphin' and 'Falklands,' 'Malvinas' or 'South America'. The Falkland Islands Government (FIG) cetacean stranding database was consulted to locate unpublished records of dusky dolphin strandings. Observations were also logged during dedicated surveys of sei whales (Balaenoptera borealis) by Falklands Conservation during 2017 and 2018 (Weir 2017, 2018). All records were plotted in Quantum Geographic Information System (QGIS), and the water depths (derived from General Bathymetric Chart of the Oceans, GEBCO) and distances from shore for each record were measured using standard QGIS scripts.

\section{Species identification}

All candidate records of dusky dolphins in the study area were investigated by the first author. Particular care was taken in distinguishing them from the Peale's dolphin, a species with which the dusky dolphin is easily confused (Crespo et al. 1997) and which is frequently-sighted on the Falklands shelf (White et al. 2002; Weir 2017, 2018). Comparisons of dusky and Peale's dolphins reveal many shared characteristics, including overall colour pattern, presence of a short beak, a bi-coloured dorsal fin (paler at the rear), a light grey thoracic patch, and a pale grey tailstock blaze with a narrow branch that projects forward onto the dorsal surface below the dorsal fin (Fig. 2). The two species are particularly difficult to tell apart when the animals are surfacing quietly and reveal only their dorsal profile (Fig. 2a), since the most unambiguous features for distinguishing between them occur on the face and lower region of the body (Fig. 2b). One major difference is the dark grey face and throat (from the eye forwards) of the Peale's dolphin, which contrasts with the clean white throat and pale grey face of the dusky dolphin and causes the beak of the latter species to appear a distinct dark grey/black colour relative to the rest of the head. Additionally, the boundary between the white ventral surface and the light grey thoracic patch is bordered by dark grey lines in Peale's dolphins, which are absent in the dusky dolphin. Finally, the thick pale grey tailstock blaze on a Peale's dolphin extends forward directly into the narrow blaze below the dorsal fin, whereas on dusky dolphins the narrow blaze separates as an offshoot from the main blaze halfway along the tailstock to result in two separate forward-projecting markings (Fig. 2b).

\section{Results}

\section{Literature review}

Previously-published records from the Falklands of animals considered to be dusky dolphins are presented in Table 1 and their locations are shown in Fig. 1. Supporting evidence was available for very few records, creating doubt over species identification. This is particularly the case with regard to the inshore sightings at West Point and Carcass Islands (Records 3, 4 and 7 in Table 1) which are areas frequently inhabited by Peale's dolphins, and with respect to Records 8 to 10 in Table 1 given the hesitation of Van Waerebeek et al. (1995) to accept unsupported records of dusky dolphins by the same observer in another geographic region.

Given such uncertainties, Van Waerebeek et al. (1995) focussed on three skulls uncovered by chance at the Natural History Museum (NHM) in London (NHMUK 1952.6.20.2, NHMUK 1952.6.20.3, and NHMUK 195 5.9.2.3) as conclusive evidence for dusky dolphin occurrence in the Falklands. Van Waerebeek et al. (1995) reported that the skulls had been collected by J.E. Hamilton, but noted that this must have occurred after Hamilton's (1952) paper on the cetacean fauna of the Falklands had been published, since that paper did not include any dusky dolphin records. Since some uncertainty surrounded the origin of the skulls, CW contacted 

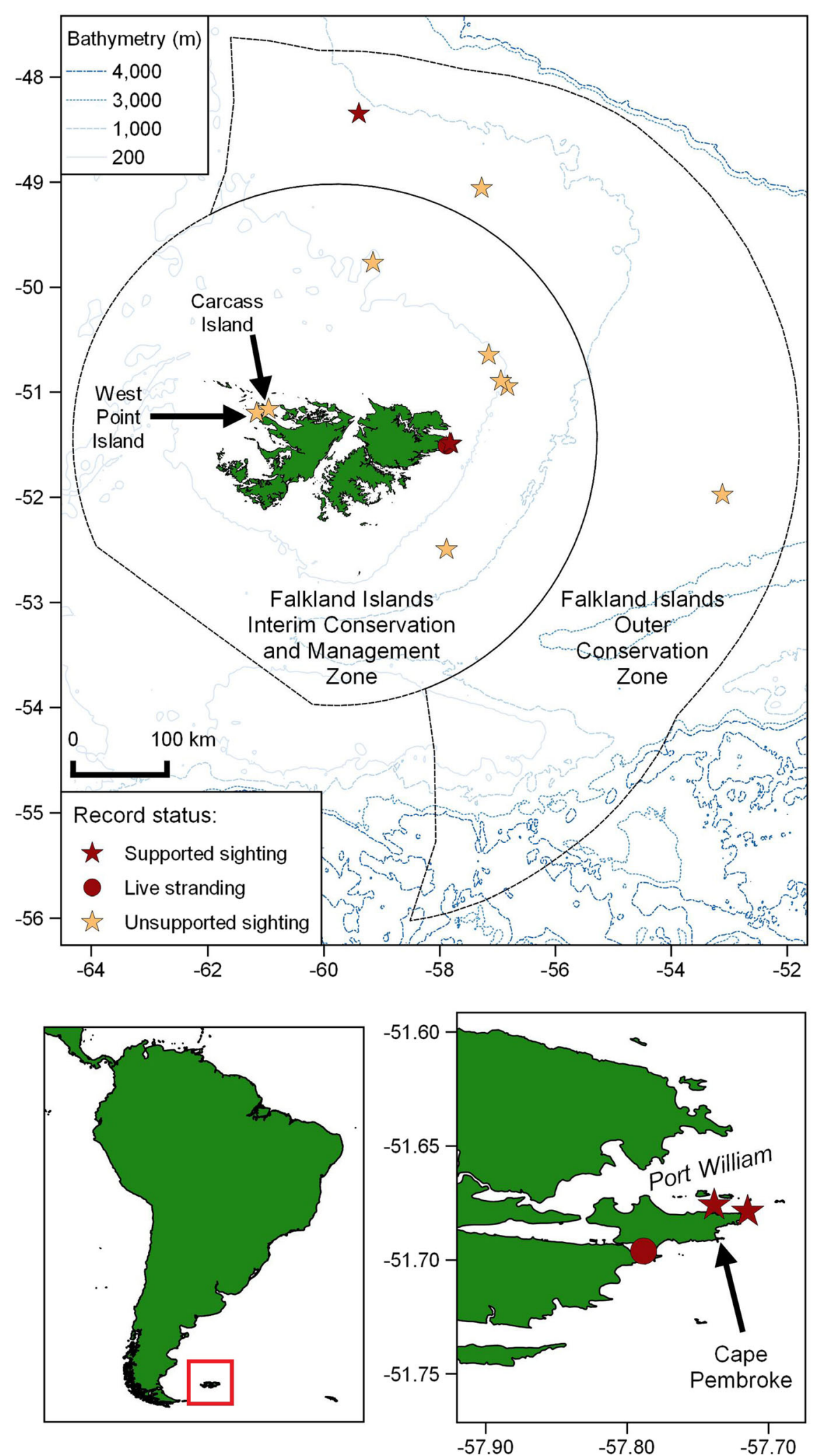

Fig. 1 The location of the Falkland Islands and the locations of the offshore and coastal dusky dolphin observations reported in this paper 

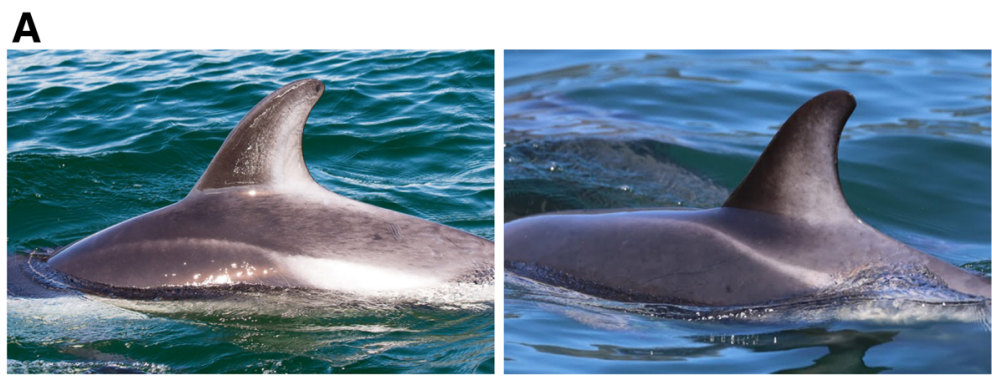

\section{B}
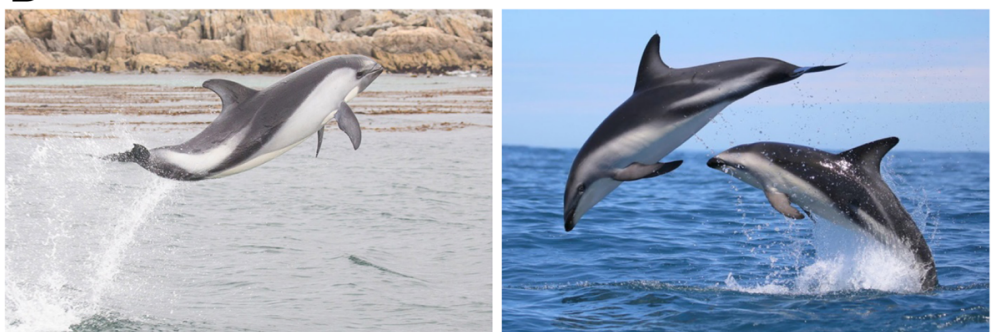

Fig. 2 Comparison of the external appearance of Peale's dolphin (left) and dusky dolphin (right) during: (a) normal surfacing; and (b) leaping behaviour. Photographs courtesy of Caroline Weir/Falklands Conservation (Peale's) and Simon Elwen/Namibian Dolphin Project (dusky)

the NHM for clarification in July 2017. Correspondence confirmed that all three skulls were indeed collected and presented to the NHM by J.E. Hamilton (NHM Mammals archive reference G.L.1948-107; Richard Sabin, pers. comm.). However, a letter relating to NHMUK 1952.6.20.2 and 1952.6.20.3 indicated that they were received by the NHM in February 1949 and that both specimens had been "caught off the Cape," casting considerable doubt (in the absence of further evidence) that they originated from the Falklands (Richard Sabin, pers. comm.). The third skull (NHMUK 1955.9.2.3) was received by the NHM on the 28 March 1955 and thus 3 years after the publication by Hamilton (1952). The skull originated from a stranded specimen, and no specific locality was described. However, Hamilton was writing from Stanley and the assumption is that the specimen did originate from the Falklands (Richard Sabin, pers. comm.). Consequently, of the three skulls described by Van Waerebeek et al. (1995), only one can be considered likely to have originated from the Falkland Islands.

Little published evidence has emerged in more recent decades to support dusky dolphin presence in the Falklands. During 3 years of extensive, targeted seabird and marine mammal surveys around the Falklands between 1998 and 2000 (White et al. 2002), 14 cetacean species were identified but there were no confirmed observations of dusky dolphins. Otley (2012) described 201 cetacean stranding events in the Falkland Islands between 1866 and 2012, including four of dusky dolphins. That paper stated that "J. Hamilton reported 4 dusky dolphin strandings during the 1950s but with no specific location information (Van Waerebeek et al. 1995)." However, as described above, only one of the three (not four) skulls reported by Van Waerebeek et al. (1995) is considered to have originated from the Falklands, and at least two of those skulls related to captures rather than strandings. Otley (2012) also mentioned, without specific details, three incidental sightings and one live stranding of a dusky dolphin in the Falkland Islands (Table 1). All four of those records were investigated, and additional information including verification photographs is presented below for two of them. Unfortunately photographs were not taken during two sightings (Records 12 and 14 in Table 1; Michael Unwin, pers. comm.), although both are considered likely to be reliable records.

\section{Verified sightings}

Four photographically-supported records of dusky dolphins in the Falklands are described below and their locations are shown in Fig. 1.

SIGHTING 1 - In January 1997 a group of six dusky dolphins was observed by $\mathrm{AB}$ from a longline fishing vessel located approximately $300 \mathrm{~km}$ north of the Falklands and inside the northern FOCZ (approximate position: $48^{\circ} 30^{\prime} \mathrm{S}$ and $59^{\circ} \mathrm{W}$ ). Water depth was approximately $800 \mathrm{~m}$. The dolphins associated closely with the vessel for 15-20 min. Photographs were taken during the encounter and clearly show the key features of dusky dolphins, particularly the pale grey face, white throat and two-pronged tailstock blaze (Fig. 3).

SIGHTING 2 - Otley (2012) made reference to a single dusky dolphin stranded alive in the Falklands during May 2008, which was subsequently refloated. 
Table 1 Summarised published records of dusky dolphins in the Falkland Islands. Record status relates to the revised information presented in this review, with 'unsupported' referring specifically to those records for which no verification information (i.e. photo or video) is available to independently confirm the species identification. All other data presented are those from the original published sources, with additional novel data acquired during this review provided in brackets

\begin{tabular}{|c|c|c|c|c|c|c|}
\hline Record & Type & $\begin{array}{l}\text { Record } \\
\text { status }\end{array}$ & Date & Location & Number & Published source \\
\hline 1 & Skulls & $\begin{array}{l}\text { Originated } \\
\text { elsewhere } \\
\text { [this paper] }\end{array}$ & 1949 & Captured off "The Cape" & 2 & $\begin{array}{l}\text { NHMUK 1952.6.20.2 and 1952.6.20.3: } \\
\text { Van Waerebeek et al. (1995); Otley (2012); } \\
\text { this paper }\end{array}$ \\
\hline 2 & Skull & Confirmed & 1955 & Falkland Islands & 1 & $\begin{array}{l}\text { NHMUK 1955.9.2.3: Van Waerebeek et al. } \\
\text { (1995); Otley (2012); this paper }\end{array}$ \\
\hline 3 & Sighting & Unsupported & 20 Jan 78 & West Point & 2 & Goodall et al. (1997) \\
\hline 4 & Sighting & Unsupported & 2 Dec 78 & West Point & 3 & Goodall et al. (1997) \\
\hline 5 & Sighting & Unsupported & 10 Jan 79 & $\begin{array}{l}130 \text { miles NE of the Falklands: } \\
49^{\circ} 14^{\prime} S, 57^{\circ} 14^{\prime} \mathrm{W}\end{array}$ & $12-20$ & Goodall et al. (1997) \\
\hline 6 & Sighting & Unsupported & 10 Jan 79 & $\begin{array}{l}45 \text { miles NE of the Falklands: } \\
50^{\circ} 50^{\prime} S, 57^{\circ} 08^{\prime} \mathrm{W}\end{array}$ & $4-8$ & Goodall et al. (1997) \\
\hline 7 & Sighting & Unsupported & 2 Jan 84 & Carcass Island: $51^{\circ} 18^{\prime} \mathrm{S}, 60^{\circ} 30^{\prime} \mathrm{W}$ & $10-12$ & Goodall et al. (1997) \\
\hline 8 & Sighting & Unsupported & 13 Aug 91 & $49^{\circ} 56^{\prime} \mathrm{S}, 58^{\circ} 51^{\prime} \mathrm{W}$ & 4 & $\begin{array}{l}\text { Van Waerebeek et al. (1995); } \\
\text { Goodall et al. (1997) }\end{array}$ \\
\hline 9 & Sighting & Unsupported & 30 Aug 91 & $51^{\circ} 08^{\prime} \mathrm{S}, 56^{\circ} 51^{\prime} \mathrm{W}$ & 11 & $\begin{array}{l}\text { Van Waerebeek et al. (1995); } \\
\text { Goodall et al. (1997) }\end{array}$ \\
\hline 10 & Sighting & Unsupported & 30 Aug 91 & $51^{\circ} 05^{\prime} \mathrm{S}, 56^{\circ} 57^{\prime} \mathrm{W}$ & 2 & $\begin{array}{l}\text { Van Waerebeek et al. (1995); } \\
\text { Goodall et al. (1997) }\end{array}$ \\
\hline 11 & Sighting & $\begin{array}{l}\text { Confirmed } \\
\text { [this paper] }\end{array}$ & [Jan 1997] & $\begin{array}{l}\text { [Approx. } 300 \mathrm{~km} \text { north of the Falklands: } \\
48-49^{\circ} \mathrm{S} \text { and } 58-60^{\circ} \mathrm{W} \text { ]. }\end{array}$ & [6] & $\begin{array}{l}\text { Andy Black pers. comm. cited in } \\
\text { Otley (2012); this paper }\end{array}$ \\
\hline 12 & Sighting & Unsupported & [8 Mar] 2007 & $\begin{array}{l}\text { East of the Falklands }\left[52^{\circ} 41.61^{\prime} \mathrm{S} 57^{\circ} 48.28^{\prime} \mathrm{W}\right] \\
\text { in } 488 \mathrm{~m} \text { water depth }\end{array}$ & 12 & $\begin{array}{l}\text { McCarthy and Unwin (2007) cited } \\
\text { in Otley (2012) }\end{array}$ \\
\hline 13 & $\begin{array}{l}\text { Live } \\
\text { stranding }\end{array}$ & $\begin{array}{l}\text { Confirmed } \\
\text { [this paper] }\end{array}$ & $\begin{array}{l}{[19 \text { Feb] }} \\
2008\end{array}$ & 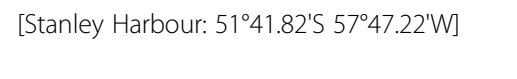 & 1 & Otley (2012); this paper \\
\hline 14 & Sighting & Unsupported & $\begin{array}{l}\text { [16 Feb } \\
2008]\end{array}$ & $\begin{array}{l}\text { [Approx. } 300 \mathrm{~km} \text { east of the Falklands } \\
\text { in } 2000 \mathrm{~m} \text { depth: } 52^{\circ} 07.20^{\prime} \mathrm{S} 53^{\circ} 30^{\prime} \mathrm{W} \text { ] }\end{array}$ & [12] & $\begin{array}{l}\text { Andy Black pers. comm. cited in } \\
\text { Otley (2012) }\end{array}$ \\
\hline
\end{tabular}

Additional information indicates that this stranding actually occurred on 19 February 2008 at the eastern end of Stanley Harbour (51 $\left.41.82^{\prime} \mathrm{S} 57^{\circ} 47.22^{\prime} \mathrm{W}\right)$.

Photographs clearly show the light grey band above the eye and clean white throat characteristic of the species

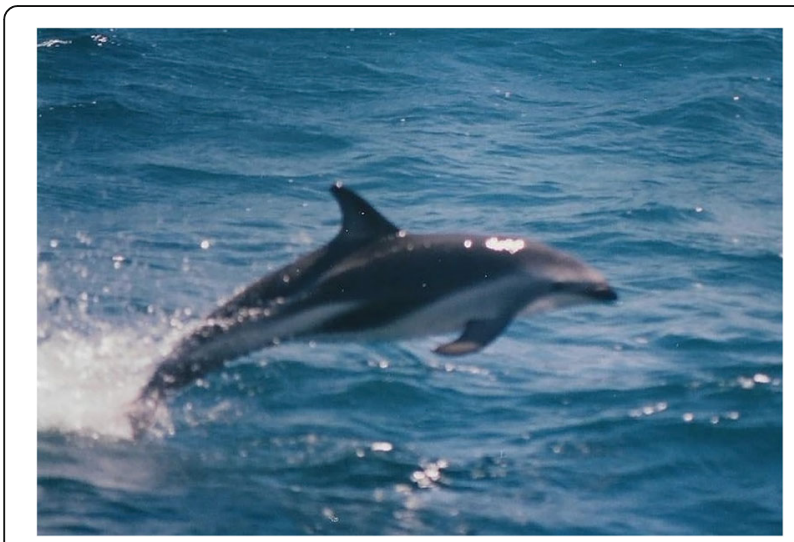

Fig. 3 Leaping dusky dolphin in the Falkland Islands Outer Conservation Zone (FOCZ) during January 1997. Photograph by Andy Black
(Fig. 4). The dolphin was loaded into a vehicle and transported the short distance to Surf Bay $\left(51^{\circ} 41.82^{\prime} \mathrm{S}\right.$, $\left.57^{\circ} 46.68^{\prime} \mathrm{W}\right)$ where it was released. A small group of dolphins (at least one of which was a Peale's dolphin) were present in Surf Bay at the time of the release.

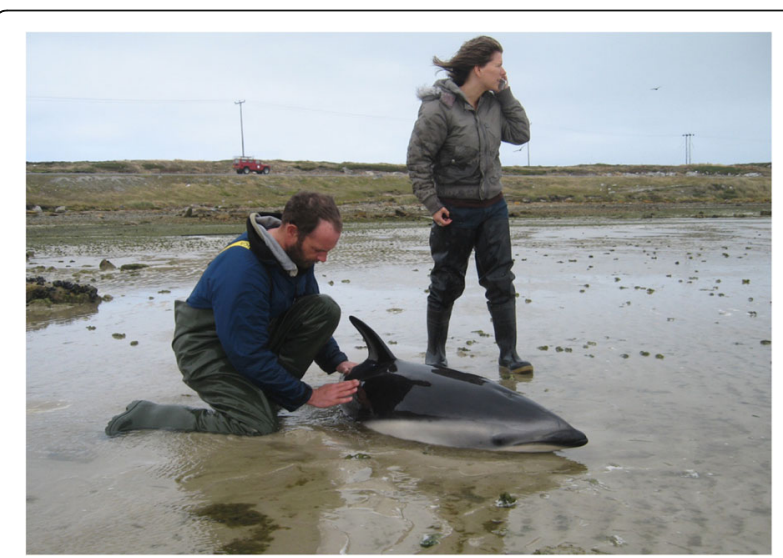

Fig. 4 A live-stranded dusky dolphin in Stanley harbour on 19 February 2008. Photograph by Anna Shepherd/Falklands Conservation 
SIGHTING 3 - On 8 May 2017, a group of eight dolphins was recorded by $\mathrm{CW}$ towards the end of a dedicated cetacean survey using a $6.5 \mathrm{~m}$ rigid-hulled inflatable boat (RHIB). The initial sighting was located approximately $200 \mathrm{~m}$ off the eastern end of the Cape Pembroke peninsula in shallow $(<10 \mathrm{~m})$ water depths $\left(51^{\circ} 40.81^{\prime} \mathrm{S}, 57^{\circ} 42.80^{\prime} \mathrm{W}\right)$. A small group of three animals was closely followed by a second group of five to six dolphins, with all of the animals approaching the boat and merging to bow-ride. The sighting occurred in poor light approximately $30 \mathrm{~min}$ prior to sunset and consequently no photo-identification images were taken. However, some above-water video footage was obtained with a GoPro, and showed that one individual bore the characteristic markings of a dusky dolphin while the remainder of the group were Peale's dolphins (Fig. 5).

SIGHTING 4 - A group of six dolphins was observed by CW on 29 May 2017 towards the end of a dedicated cetacean survey from a RHIB. The sighting occurred in shallow water $(<10 \mathrm{~m})$ inside Port William $\left(51^{\circ} 40.63^{\prime} \mathrm{S}\right.$, $\left.57^{\circ} 44.21^{\prime} \mathrm{W}\right)$. The dolphins actively approached the boat to bow-ride and spent approximately $20 \mathrm{~min}$ in the vicinity of the boat. Since the sighting occurred in poor light an hour prior to sunset and with overcast skies, no photo-identification images were taken. However, some underwater video footage was taken of the group using a GoPro, and revealed that one of the animals was a dusky dolphin while the remainder comprised Peale's dolphins (Fig. 6).

\section{Discussion}

Crespo et al. (1997) reported that dusky and Peale's dolphins can be very easily confused at sea due to their similar colour pattern, and that care is therefore required when considering sightings in geographic regions where both species occur. Goodall et al. (1997) similarly noted that the

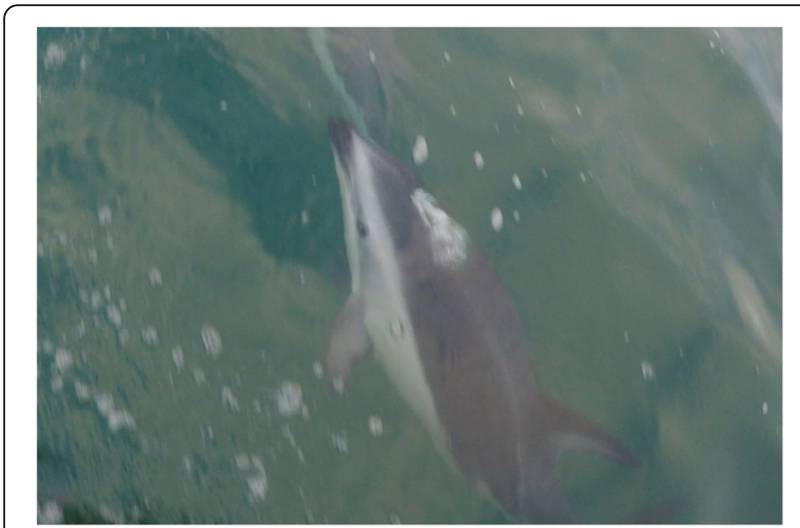

Fig. 5 Dusky dolphin bow-riding a boat with Peale's dolphins in Port William on 8 May 2017. A still taken from GoPro video by Caroline Weir/Falklands Conservation
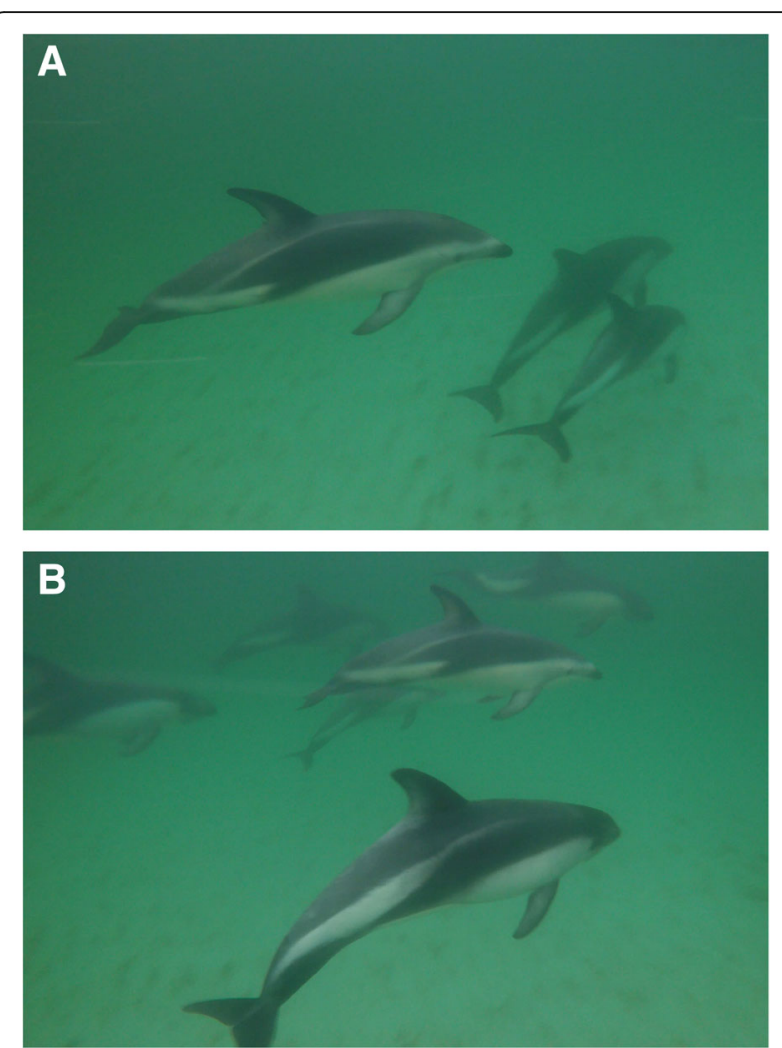

Fig. 6 A dusky dolphin (left animal in Part a, and upper central animal in Part b) associated with Peale's dolphins in Port William on 29 May 2017. Stills taken from GoPro video by Caroline

Weir/Falklands Conservation

two species are only reliably identified by experienced observers. Van Waerebeek et al. (1995) concluded that many reports of dusky dolphins around Southern Hemisphere island groups were erroneous or unsubstantiated, and our review established that most previously-published dusky dolphin records from the Falklands could not be confirmed due to the absence of supporting information. We also found that field identification can be further complicated by the documentation of mixed-species associations between dusky and Peale's dolphins, necessitating careful examination of all individuals within a group.

This paper reviewed early records of dusky dolphins in the Falkland Islands and presented four photographicallysupported observations. Only one record, a skull collected in 1955, could be confirmed prior to the 1990s. The locations of several of the unsupported sightings corresponded with the approximate position of the $200 \mathrm{~m}$ depth isobath (Fig. 1), and Peale's dolphins were recorded in those same areas by White et al. (2002). However, three sightings in the FOCZ were in deep waters unlikely to represent habitat for Peale's dolphins, and at least one of those sightings was confirmed as dusky dolphins in this paper. It is plausible that shelf occurrences of dusky dolphins in the Falklands have gone unnoticed due to the assumption that all 
encountered dolphins of that general appearance are Peale's dolphins, a species which is comparatively widespread and numerous across the Falklands shelf (White et al. 2002; Weir 2018).

When discussing the status of dusky dolphins in the Falklands, Otley et al. (2008) considered the species to be a vagrant, while Otley (2012) surmised that it was a rare visitor to offshore waters. The four photographically-verified records described in this paper provide little clarification regarding the overall status of the species, especially since three of them comprised a single dusky dolphin and may to some extent be atypical (particularly the live stranding). Furthermore, the two sightings on 8 and 29 May 2017 comprised the same individual dusky dolphin, as evidenced by a large nick in the trailing edge of its dorsal fin. The live stranded animal in 2008 did not have a dorsal nick, and therefore it can only be speculated whether this may be the same individual. The absence of further verified sightings in coastal or offshore habitat suggests that dusky dolphins are not numerous in Falkland waters. Additionally, a recent 6-week cetacean survey of Falkland shelf waters recorded 170 sightings of Peale's dolphins but no confirmed dusky dolphins (Weir 2018). However, cetacean survey work in the Falklands is still in its infancy, and the status of dusky dolphins in the region remains unclear.

The two observations reported from May 2017 apparently represent the first reports of mixed-species associations between Peale's and dusky dolphins. It is possible that the occurrence of this individual dusky dolphin among Peale's dolphins is unusual and does not necessarily imply regular mixed-species associations between the two species in the Falklands or elsewhere. However, the records highlight the need to carefully check and identify all animals rather than assuming mono-specific groups. In the south-west Atlantic, Peale's and dusky dolphins are commonly perceived to be largely allopatric, but Crespo et al. (1997) reported that a considerable degree of sympatry exists between their distributions although they may occupy different habitats. The relative occurrence of the two species at latitudes between 47 and $55^{\circ} \mathrm{S}$ is particularly unclear (Crespo et al. 1997), with dusky dolphins being more numerous north of $47^{\circ} \mathrm{S}$ while Peale's are more frequent south of $47^{\circ} \mathrm{S}$ and especially in coastal areas. Thus the Falklands are located within the latitudes where both species are expected to overlap and where a transition in their relative abundance may occur.

\section{Conclusions}

Our review clarifies current knowledge of dusky dolphins in the Falklands, indicating that the species is present but not numerous. We also provide the first information on mixed-species associations with Peale's dolphins, and confirm dusky dolphin presence in both coastal and offshore habitat around the Islands. There are implications for visual cetacean surveys in the Falklands, particularly with regard to brief or distant dolphin observations (e.g. from land or during aerial surveys) where the potential for misidentifications increases. Observers should be alert to the possibility of mixed-species groups and collect supporting information for sightings whenever possible to facilitate subsequent verification of species identification.

\section{Acknowledgements \\ Our grateful thanks to Richard Sabin of the Natural History Museum (London, UK) for checking the archives relating to the origin of the three dusky dolphin skulls mentioned in this paper. Thanks to Sarah Crofts (Falklands Conservation) for locating archive material on the dusky dolphin live stranding in 2008. Simon Elwen kindly supplied images of dusky dolphins. Our thanks for the comments of two reviewers which improved this manuscript.}

\section{Funding}

The sei whale survey work in 2017, during which two dusky dolphin observations were recorded, was funded by the European Union BEST 2.0 Programme. Falklands Conservation receives funding from Falkland Islands Government for attending cetacean strandings. The authors received no funding in specific relation to the production of this paper.

\section{Availability of data and materials}

The datasets used and/or analysed during the current study are available from the corresponding author on reasonable request.

\section{Authors' contributions}

$A B$ and $C W$ recorded the sighting data presented here. $C W$ produced the manuscript. Both authors approved the final manuscript.

\section{Ethics approval and consent to participate}

For the stranded animal management and sei whale boat survey work, relevant approval and licenses were issued to Falklands Conservation by the Falkland Islands Government.

Consent for publication

Not applicable.

\section{Competing interests}

The authors declare that they have no competing interests.

\section{Publisher's Note}

Springer Nature remains neutral with regard to jurisdictional claims in published maps and institutional affiliations.

\section{Author details}

${ }^{1}$ Falklands Conservation, Jubilee Villas, Stanley FIQQ 1ZZ, Falkland Islands. ${ }^{2}$ South Atlantic Environmental Research Institute, Stanley Cottage, Stanley FIQQ 1ZZ, Falkland Islands.

Received: 26 April 2018 Accepted: 30 July 2018

Published online: 10 August 2018

\footnotetext{
References

Cipriano F, Webber M. Dusky dolphin life history and demography. In: Würsig B, Würsig M, editors. The dusky dolphin: master acrobat off different shores. London: Academic Press; 2010. p. 21-48.

Crespo EA, Pedraza SN, Coscarella M, García NA, Dans SL, Iñíguez M, Reyes LM, Alonso MK, Schiavini ACM, González R. Distribution and school size of dusky dolphins, Lagenorhynchus obscurus (gray, 1828), in the southwestern South Atlantic Ocean. Rep Int Whal Commn. 1997;47:693-8.

Goodall RNP, de Haro JC, Iñíguez MA, Norris KS. Sightings and behaviour of Peale's dolphins, Lagenorhynchus australis, with notes on dusky dolphins, L.
} 
obscurus, off southernmost South America. Rep Int Whal Commn. 1997;47: $757-75$.

Hamilton JE. Cetacea of the Falkland Islands. Comun Zool Mus Hist nat Montev. 1952;4:1-6.

Hammond PS, Bearzi G, Bjørge A, Forney K, Karczmarski L, Kasuya T, Perrin WF, Scott MD, Wang JY, Wells RS, Wilson B. Lagenorhynchus obscurus. The IUCN Red List of Threatened Species. 2008. https://doi.org/10.2305/IUCN.UK.2008. RLTS.T11146A3257285.en. Accessed 24 Jan 2017.

Harlin-Cognato AD, Honeycutt RL. Multi-locus phylogeny of dolphins in the subfamily Lissodelphininae: character synergy improves phylogenetic resolution. BMC Evol Biol. 2006;6:87. https://doi.org/10.1186/1471-2148-6-87.

Otley $\mathrm{H}$. The composition of the cetacean community in the Falkland (Malvinas) islands, southwest South Atlantic Ocean. Rev Biol Mar Oceanogr. 2012;47: 537-51.

Otley H, Munro G, Clausen A, Ingham B. Falkland Islands state of the environment report. Stanley, Falkland Islands: Falkland Islands Government and Falklands Conservation; 2008.

Van Waerebeek K, Van Bree PJH, Best PB. On the identity of Prodelphinus petersii Lutken, 1889 and records of dusky dolphin Lagenorhynchus obscurus (gray, 1828) from the southern Indian and Atlantic oceans. South Afr J Mar Sci. 1995;16:25-35.

Weir CR. Developing a site-based conservation approach for sei whales Balaenoptera borealis at Berkeley sound, Falkland Islands. Stanley, Falkland Islands: Falklands Conservation; 2017.

Weir CR. A preliminary assessment of endangered sei whales (Balaenoptera borealis) in two candidate key biodiversity areas in West Falkland. Stanley, Falkland Islands: Falklands Conservation; 2018.

White RW, Gillon KW, Black AD, Reid JB. The distribution of seabirds and marine mammals in Falkland Islands waters. Peterborough, UK: Joint Nature Conservation Committee; 2002

Ready to submit your research? Choose BMC and benefit from:

- fast, convenient online submission

- thorough peer review by experienced researchers in your field

- rapid publication on acceptance

- support for research data, including large and complex data types

- gold Open Access which fosters wider collaboration and increased citations

- maximum visibility for your research: over $100 \mathrm{M}$ website views per year

At $\mathrm{BMC}$, research is always in progress.

Learn more biomedcentral.com/submissions 